\title{
Evaluation of Insertion/deletion (I/D) \\ Polymorphisms of ACE Gene in Congenital Anomalies of The Kidney and Urinary Tract From a Brazilian Pediatric Population
}

\section{Pedro Antunes Pousa}

UFMG: Universidade Federal de Minas Gerais

Tamires Sara Campos Mendonça

UFMG: Universidade Federal de Minas Gerais

\section{Larissa Marques Fonseca}

UFMG: Universidade Federal de Minas Gerais

\section{Eduardo Araújo Oliveira}

UFMG: Universidade Federal de Minas Gerais

\section{André Rolim Belisário}

UFMG: Universidade Federal de Minas Gerais

Ana Cristina Simões e Silva ( $\square$ acssilva@hotmail.com )

Federal University of Minas Gerais https://orcid.org/0000-0001-9222-3882

\section{Research Article}

Keywords: CAKUT, ACE I/D polymorphisms, ureteropelvic junction obstruction, vesicoureteral reflux, multicystic dysplastic kidney

Posted Date: May 18th, 2021

DOI: https://doi.org/10.21203/rs.3.rs-506874/v1

License: (c) (i) This work is licensed under a Creative Commons Attribution 4.0 International License. Read Full License 


\section{Abstract}

Background: Congenital Anomalies of the Kidney and the Urinary Tract (CAKUT) are defined as a heterogeneous group of anomalies that resulted from defects in kidney and urinary tract embryogenesis. CAKUT have a complex etiology. Genetic, epigenetic and environmental factors have been investigated in this context. Angiotensin II is a potent vasoconstrictor and exerts an important role in kidney embryogenesis. The angiotensin-converting enzyme (ACE) converts Angiotensin I into Angiotensin II and $A C E$ gene has insertion/deletion (I/D) polymorphisms that have been evaluated in several nephropathies. This study aimed to evaluate whether the I/D polymorphisms of ACE gene are associated with any CAKUT phenotype or CAKUT in general.

Methods and Results: Our study was performed with 225 pediatric patients diagnosed with CAKUT and 210 age-and-sex matched healthy controls. ACE I/D alleles were analysed by real-time polymerase chain reaction (RT-PCR). The distribution of $A C E \mathrm{I} / \mathrm{D}$ polymorphisms were compared between CAKUT patients and healthy controls, as well between ureteropelvic junction obstruction (UPJO), vesicoureteral reflux (VUR), multicystic dysplastic kidney (MCDK) phenotypes and control group. No statistical association of $A C E \mathrm{I} / \mathrm{D}$ genotypes and allelic frequency between patients and controls was found among general CAKUT and UPJO, VUR and MCDK phenotypes.

Conclusion: Although CAKUT is a complex disease and the ACE gene may exert a role in kidney embryogenesis, CAKUT was not associated with any ACE I/D polymorphisms in this Brazilian pediatric population.

\section{Introduction}

Congenital Anomalies of the Kidney and Urinary Tract (CAKUT) consist of heterogeneous defects of the kidney and urinary tract embryogenesis (Schütz et al. 1996). These anomalies are a common cause of end stage renal disease (ESRD) in children (Heikkila et al. 2011). The most common phenotypes are ureteropelvic junction obstruction (UPJO), vesicoureteral reflux (VUR), multicystic dysplastic kidney (MCDK), horseshoe kidney, renal agenesis, duplex collecting system, renal hypoplasia, megaureter, posterior urethral valves and ureterocele (Negrisolo et al. 2011).

CAKUT occur in 0.5 to $6 \%$ of all pregnancies (Melo et al. 2012; Qurino et al. 2012; Fletcher et al. 2013; Finer et al 2007) and have a complex etiology, influenced by genetic, epigenetic and environmental factors. Several genes have been investigated in the context of CAKUT (Miranda et al. 2014a; Miranda et al 2014b; Rahimi et al 2012). The insertion/deletion (I/D) polymorphisms of the angiotensin-converting enzyme (ACE) gene have been evaluated in several nephropathies (Yu et al. 2012; Sayed-Tabatabaei et al. 2006). This gene has an autosomal recessive mode of inheritance and is responsible for the synthesis of ACE, the enzyme that converts angiotensin I (Ang I) into angiotensin II (Ang II) (Simões e Silva et al. 2020). Ang II has an important role in vasoconstriction and aldosterone release, being one of the main mediators of the renin-angiotensin system (RAS) (Santos-Junior et al. 2014). During embryogenesis, Ang 
II exerts a role in kidney tissue development by acting via angiotensin type 2 receptor (AT2R) (Zhang et al. 2004). Accordingly, polymorphisms of the gene that encodes AT2R have been previously associated with UPJO in our population of CAKUT patients [9].

To further extend our investigation of genes related to CAKUT in Brazilian population, this study aimed to evaluate I/D polymorphisms of the ACE gene in our patients. Data were compared to healthy controls matched by sex and age. In addition, we also investigated if the three most common phenotypes of CAKUT, including UPJO, RVU and MCDK, were associated with the I/D polymorphisms of ACE gene.

\section{Patients And Methods}

\section{Congenital Anomalies of the Kidney and Urinary Tract Group}

This study included 225 pediatric patients of the Pediatric Nephrology Unit of Federal University of Minas Gerais (Brazil) with antenatal diagnosis of renal and/or urinary tract malformations. In order to participate in the study, all parents consent was obtained. Blood samples for genetic studies were collected in a single occasion from March of 2013 to April of 2014. Measurement of renal pelvis dilatation (RPD) was made based on the assessment of the anteroposterior diameter of the renal pelvis in prenatal ultrasound. Patients with RPD $>5 \mathrm{~mm}$ or findings suggestive of MCDK in prenatal ultrasound were considered suitable for our study. Chromosome disorders and multiple major malformations were considered as exclusion criteria. Patients had a mean age of $6.4 \pm 2.8$ years old (range: 1.8 -13.3 years old) at the time of blood collection and were from the southeast region of Brazil.

A systematic protocol for diagnostic confirmation and phenotype stratification was made before and after birth. A detailed prenatal ultrasonography (US) was performed after 28 weeks of gestation (Melo et al. 2012; Quirino et al. 2012) at our Centre of Fetal Medicine for RPD screening. After birth, infants with prenatally suspected CAKUT were prospectively followed up at our Pediatric Nephrology Unit. The protocol included an US at the first 7-15 days of postnatal life, a voiding cystourethrogram (VCUG) and antibiotic prophylaxis during the first day of postnatal life and maintained according to the diagnosis. US scans, clinical examination, and laboratory reviews were scheduled at 1 to 6-month intervals according to previous findings. When the VCUG was normal but postnatal US showed antero-posterior diameter (APD) of renal pelvis equal to or higher than $10 \mathrm{~mm}$, renal scintigraphy was performed after the first month of life (Quirino et al. 2012). CAKUT diagnosis was assessed based on the combination of data obtained by VCUG, renal scintigraphy, and sequential US. All patients who did not perform the above-mentioned protocol were excluded from the study.

Further, CAKUT-confirmed patients were stratified in groups based on the etiology of malformation. The absence of any recognized uropathy was classified as idiopathic hydronephrosis. MCDK was defined when cysts of various sizes without connection between them were located in parenchyma of a structurally abnormal kidney in which no renal pelvis could be demonstrated (Rabelo et al. 2005). VUR was characterized by the return of urine from bladder to renal pelvis and the diagnosis was confirmed and graded by VCUG according to the international grading system. Ureteropelvic junction obstruction 
(UPJO) was defined as the presence of moderate or severe hydronephrosis in the US associated with an abnormal dynamic renal scintigraphy (DTPA) pattern (Dias et al. 2013).

\section{Control Group}

The control group included 210 healthy sex- and age matched subjects from the same geographic area as our patients. All controls were normotensive and had serum creatinine within the normal range at the time of blood sampling. A family history of any kind of renal disease, urinary tract malformation, or urinary tract infection automatically excluded the subject. Healthy status was also determined through the medical history and either a parental report or self-report to rule out the presence of chronic or acute diseases.

\section{Ethical Aspects}

This study was approved by our local Ethics Committee. Informed consent was obtained from the parents and, when appropriate, also from CAKUT cases and healthy controls included in the study. All parents, CAKUT patients, and healthy controls gave consent and assented to participate in this study. The research protocol did not interfere with any medical recommendations or prescriptions.

\section{Investigation of ACE I/D polymorphisms}

Peripheral blood was collected in ethylenediaminetetraacetic acid (EDTA) vacuum tubes from all participating individuals. For investigation of the ACE I/D polymorphisms, genomic DNA of leukocytes were extracted from blood and purified using the Wizard purification system (Promega Inc., Madison, WI, USA), following the manufacturer instructions. Angiotensin-converting enzyme insertion/deletion (I/D) polymorphisms (rs4646994) were genotyped using real-time Polymerase Chain Reaction (PCR) and melting curve analysis with SYBR Green. All real-time PCR genotyping assays were performed using a StepOne Real-time PCR system (Applied Biosystems, Foster City, CA, USA). For further confirmation, 20\% of the samples were retested to validate the results.

\section{Statistical analysis}

Association between phenotype groups and I/D polymorphisms was evaluated using UNPHASED version 3.1.7 (Frank Dudbridge, MRC Biostatistics Unit, Cambridge, UK). Differences between genotype distribution and allele frequency were tested by Chi-square test. In each association test, a total of 1,000 random permutations were performed to internally validate the association between I/D polymorphism and groups. Statistical significance was defined as P-values $<0.05$. The software Haploview was used to test the Hardy Weinberg equilibrium (HWE).

\section{Results}

This study analysed 225 cases of CAKUT. Among these, there were 59 cases of ureteropelvic junction obstruction (UPJO), 51 cases of vesicoureteral reflux (VUR) and 51 cases of multicystic dysplastic kidney 
(MCDK). The remaining cases were of kidney hypoplasia, ureterocele, renal agenesis, Prune Belly syndrome, posterior urethral valve, duplication of the urinary tract or megaureter. For the control group, 210 healthy individuals sex and age-matched with CAKUT cases were used for comparison. The results were shown in four tables, one including all cases of CAKUT and the other three were specific to each of the main phenotypes, including UPJO, VUR and MCDK.

In table 1, among the 225 CAKUT cases, there were 74 individuals with double deletion of the ACE gene, DD genotype, corresponding to $32.9 \%$ of the entire group, 110 cases of ID genotype, one insertion allele and one deletion, accounting for $48.9 \%$ and 41 cases of double insertion, II genotype, representing $18.2 \%$. The frequency of the allele D was $57.3 \%$, while the allele I was $42.7 \%$. In regard to the control group, among the 210 individuals, there were 67 (31.9\%) cases of DD, 107 (51\%) cases of ID and $36(17.1 \%)$ cases of II. The frequency of the allele D was $57.4 \%$, whereas allele I occurred in $42.6 \%$. The comparison between genotypes and allele frequencies did not show differences between CAKUT cases and controls (Table I).

In table 2, among the 59 cases of UPJO, 23 (38.9\%) had the genotype DD, 25 (42.4\%) were ID and 11 $(18.6 \%)$ were II. The frequency of the allele $D$ was $60.2 \%$ and of the allele I was $39.8 \%$. The comparison between UPJO subgroup and controls in regard to genotype and allele frequencies revealed similar distributions without statistical differences (Table 2).

Table 3 displays data of 51 cases of VUR and 210 controls. Of the 51 individuals with VUR, $23(2.1 \%)$ were DD, 41 (51.9\%) were ID and $15(19 \%)$ had the genotype II. The alleles frequencies were $55.1 \%$ for $D$ and $44.9 \%$ for I. No significant differences were found for the genotypes and alleles frequencies between patients with VUR and controls (Table 3 ).

Table 4 shows cases of MCDK and controls. There were 51 patients with MCDK, being 19 (36.5\%) with the genotype DD, 23 (44.2\%) presenting ID and 10 (19.2\%) with II genotype. The alleles frequencies were $58.7 \%$ for $D$ and $41.3 \%$ for I. Once again, cases of MCDK and controls did not differ concerning genotypes and alleles frequencies (Table 4).

\section{Discussion}

CAKUT refer to a diverse group of kidney and urinary tract anomalies due to defects in kidney embryonic development. Genetic and phenotype heterogeneity and incomplete genetic penetrance are factors that challenge the genetic diagnosis of the disease (Nicolau et al. 2015). Therefore, the pathogenesis of CAKUT can be multifactorial and associated with epigenetic and environmental factors.

Our research group performed previous studies with the same group of patients. Miranda et al. showed that PAX2 gene polymorphisms were associated with VUR in our sample, but not with UPJO and MCDK (Miranda et al. 2014a). In another study, an association between $A T 2 R$ gene and UJPO was detected, suggesting that AT2R was involved in the pathogenesis of CAKUT and that phenotype expression would vary according to the genetic origin of the disease (Miranda et al. 2014b). The current study was 
performed in order to evaluate whether an association of I/D polymorphisms of ACE gene and CAKUT would occur or if the polymorphisms would be associated with a specific phenotype of CAKUT in Brazillian population.

ACE is a RAS component that converts Ang I into Ang II. Ang II is a potent vasoconstrictor that exerts an essential role in blood pressure control, by promoting vasoconstriction and by releasing Aldosterone, which increases the reabsorption of sodium and water from urine (Simões e Silva et al. 2020; SantosJunior et al. 2014). As mentioned, ACE gene has insertion and deletion polymorphisms on intron 16, which are suggested to be associated with some clinical outcomes related to blood pressure, atherosclerosis, diabetic nephropathy, muscle performance, Alzheimer disease and longevity (SayedTabatabaei et al. 2006). Previous studies had shown that $D$ alleles are related to greater serum activity of ACE (Rigat et al. 1990), however the functionality of this polymorphism is not well elucidated (SayedTabatabaei et al. 2006). Our main hypothesis for this study was that ACE I/D polymorphisms could influence ACE serum activity, changing the concentrations of Ang I and of Ang II.

The metanephros are the definitive kidney of mammals. Its embryogenesis is resulted from reciprocal interactions between the ureteric bud (UB) and the metanephric mesenchyme. UBs will develop into the collecting ducts, pelvis and the ureteric epithelia, while the metanephric mesenchyme is responsible for ureteric branching and nephrogenesis, by differentiation of mesenchymal cells into epithelial cells of the nephron (Serqueira and Gomez 2004). In this regard, an intact RAS is required for normal kidney development (Guron and Friberg 2000). Ang II promotes UB cell branching in collagen gel cultures in vitro, induces UB morphogenesis in intact whole embryonic metanephros grown ex vivo, stimulates tyrosine phosphorylation of the epidermal growth factor receptor (EGFR) in UB cells and promotes directional migration of UB cells (Yosypiv, 2008; Song et al. 2011). Additionally, Zhang et al. (2004) showed that Ang II is involved in kidney embryogenesis by increasing paired homeobox 2 gene (PAX-2) expression in fetal kidney cells via the AT2R, by downregulating or desensitizing this receptor. According to Song et al. (2010), AT2R-deficient mice present abnormal ureteric bud (UB) budding, increased incidence of double ureters and vesicoureteral reflux. In contrast, this association was not found in a study with 66 japanese boys with CAKUT and healthy controls, as they showed no evidence for $A T 2 R$ gene derangement in human urinary tract anomalies (Hiraoka et al. 2001).

For this analysis, we hypothesized that greater occurrence of DD genotypes and D allele frequency would cause an elevation of Ang II levels by increasing serum activity of ACE. Greater prevalence of II genotype and I allele frequency would have the opposite effect, reducing Ang II levels (Rigat et al. 1990). However, our study did not find any association between ACE I/D polymorphisms and CAKUT in general or CAKUT specific phenotypes. Genotype distribution and allele frequency were very similar in both healthy controls and CAKUT patients. When it comes to specific phenotypes of CAKUT, UPJO and MCDK phenotypes were slightly associated with DD genotypes, but this trend did not achieve statistical significance. Children with VUR had genotypes and alleles frequencies very similar to healthy controls. 
Literature data is controversial. A meta-analysis showed that $D$ allele and DD genotype are risk factors for the VUR susceptibility/renal scar in Turkish children (Zhou et al. 2012). In contrast, a bulgarian study performed by Kostadinova and colleagues (2017) found no significant association between ACE I/D genotype and CAKUT phenotypes, supporting our findings. Additionally, this bulgarian research group also showed that the highest serum ACE level encoded by ACE I/D polymorphisms was associated with higher risk of severe hydronephrosis in Bulgarian patients with obstructive uropathies (Kostadinova et al. 2017). Unfortunately, these findings were not analysed in our study.

This study has several limitations. First of all, CAKUT is defined as a complex multifactorial disease and may have several variables that contribute to the presented phenotype (Nicolau et al. 2015). Second, as mentioned, the functionality of $A C E \mathrm{I} / \mathrm{D}$ polymorphisms are not well elucidated. It is suspected that a polymorphism on intron 18 , rather than on intron 16 , is more likely to be functional on ACE serum activity (Sayed-Tabatabaei et al. 2006). Nonetheless, intron 16 is still used as a marker due to tight relationship with ACE levels. Finally, an genetic-epidemiological approach would provide more information by including environmental factors associated with CAKUT.

Genetic, epigenetic and environmental factors might be involved in the pathogenesis of CAKUT (Nicolau et al. 2015). We did not find any association between ACE I/D polymorphisms and CAKUT in Brazilian children. DD genotypes were slightly increased in patients with UPJO and MCDK, but did not achieve statistical significance. However, this study still contributes to the understanding of CAKUT origins in the Brazilian population. In the future, we believe that further studies with genetic-epidemiological approaches would contribute to the investigation of CAKUT.

\section{Declarations}

Funding: This work was partially supported by Brazilian National Council of Research Development (CNPq - Grant \# 302153/2019-5), Coordination of High Education Level Personnel (CAPES) and Foundation of Research of Minas Gerais (FAPEMIG).

Conflicts of interest: none declared

Ethics approval: This study was approved by the local Ethics Committee

Consent to participate: All subjects involved in this study gave consent and assented to participate in this study

Consent for publication: All subjects involved in this study gave consent and assented for publication Availability of data and material: Not applicable

Code availability: Not applicable 
Authors' contributions: PAP, TSCM and LMF wrote the first draft. ARB performed laboratorial and statistical analyses. ACSS and ARB conceptualized the study, made general supervision and revised the manuscript. ACSS submitted the final version of the manuscript, which is approved by all authors.

\section{References}

1. Dias CS, Silva JMP, Pereira AK, Marino VS, Silva LA, Coelho AM et al (2013) Diagnostic accuracy of renal pelvic dilatation for detecting surgically managed ureteropelvic junction obstruction. J Urol 190:661-666

2. Finer G, Shalev H, Landau D (2006) Genetic kidney diseases in the pediatric population of southern Israel. Pediatr Nephrol 21(7):910-916

3. Fletcher J, McDonald S, Alexander SI, Australian and New Zealand Pediatric Nephrology Association (ANZPNA) (2013) Prevalence of genetic renal disease in children. Pediatr Nephrol 28(2):251-256

4. Guron G, Friberg P (2000) An intact renin - angiotensin system is a prerequisite for normal renal development. J Hypertens 18(2):123-137

5. Heikkila J, Holmberg C, Kyllonen L, Rintala R, Taskinen S (2011) Longterm risk of end stage renal disease in patients with posterior urethral valves. J Urol 186:2392-2396

6. Hiraoka M, Taniguchi T, Nakai H, Kino M, Okada Y, Tanizawa A et al (2001) No evidence for AT2R gene derangement in human urinary tract anomalies. Kidney Int 59:1244-1249

7. Kostadinova ES, Miteva LD, Stanilova SA (2017) ACE serum level and I/D gene polymorphism in children with obstructive uropathies and other congenital anomalies of the kidney and urinary tract. Nephrology (Carlton) 22:609-616

8. Melo BF, Aguiar MB, Bouzada MC, Aguiar RL, Pereira AK, Paixao GM, Linhares MC, Valerio FC, Simões e Silva AC, Oliveira EA (2012) Early risk factors for neonatal mortality in CAKUT: analysis of 524 affected newborns. Pediatr Nephrol 27(6):965-972

9. Miranda DM, Dos Santos Júnior ACS, Dos Reis GS, Freitas IS, Carvalho TGR, de Marco LAC et al (2014) PAX2 polymorphisms and congenital abnormalities of the kidney and urinary tract in a Brazilian pediatric population: evidence for a role in vesicoureteral reflux. Mol Diagn Ther 18:451457

10. Miranda DM, Santos AC dos, Sarubi HC, Bastos-Rodrigues L, Rosa DV, Freitas IS et al (2014) Association of angiotensin type 2 receptor gene polymorphisms with ureteropelvic junction obstruction in Brazilian patients. Nephrology 19:714-720

11. Negrisolo S, Benetti E, Centi S, Vella MD, Ghirardo G, Zanon G et al (2011) PAX2 gene mutations in pediatric and young adult transplant recipients: kidney and urinary tract malformations without ocular anomalies. Clin Genet 80(6):581-585

12. Nicolaou N, Renkema KY, Bongers EMHF, Giles RH, Knoers NVAM (2015) Genetic, environmental, and epigenetic factors involved in CAKUT. Nat Rev Nephrol 11:720-731 
13. Quirino IG, Diniz JS, Bouzada MC, Pereira AK, Lopes TJ, Paixão GM et al (2012) Clinical course of 822 children with prenatally detected nephrouropathies. Clin J Am Soc Nephrol 7(3):444-451. https://doi.org/10.2215/CJN.03400411

14. Rabelo EAS, Oliveira EA, Silva JMP, Bouzada MCF, Sousa BC, Almeida MN et al (2005) Conservative management of multicystic dysplasic kidney: clinical course and ultrasound outcome. J Pediatr (Rio J) $81(5): 400-404$

15. Rahimi Z (2012) ACE insertion/deletion (I/D) polymorphism and diabetic nephropathy. J Nephropathol 1:143-151

16. Rigat B, Hubert C, Alhenc-Gelas F, Cambien F, Corvol P, Soubrier F (1990) An insertion/deletion polymorphism in the angiotensin l-converting enzyme gene accounting for half the variance of serum enzyme levels. J Clin Invest 86:1343-1346

17. Santos-Junior ACS, Miranda DM, Simões e Silva AC (2014) Congenital anomalies of the kidney and urinary tract: An embryogenetic review. Birth Defects Research Part C: Embryo Today: Reviews 102:374-381

18. Sayed-Tabatabaei FA, Oostra BA, Isaacs A, van Duijn CM, Witteman JCM (2006) ACE Polymorphisms. Circulation Research 98: 1123-33

19. Schütz S, Le Moullec JM, Corvol P, Gasc JM (1996) Early expression of all the components of the renin-angiotensin-system in human development. Am J Pathol 149:2067-2079

20. Sequeira Lopez MLS, Gomez RA (2004) The role of angiotensin II in kidney embryogenesis and kidney abnormalities. Curr Opin Nephrol Hypertens 13:117-122

21. Simões e Silva AC, Lanza K, Palmeira VA, Costa LB, Flynn JT (2020) 2020 update on the reninangiotensin-aldosterone system in pediatric kidney disease and its interactions with coronavirus. Pediatr Nephrol. https://doi.org/10.1007/s00467-020-04759-1

22. Song R, Preston G, Yosypiv IV (2011) Angiotensin II stimulates in vitro branching morphogenesis of the isolated ureteric bud. Mech Dev 128:359-367

23. Song R, Spera M, Garrett C, El-Dahr SS, Yosypiv IV (2010) Angiotensin II AT2 receptor regulates ureteric bud morphogenesis. Am J Physiol Renal Physiol 298:F807-F817

24. Yosypiv IV (2008) A New Role for the Renin-Angiotensin System in the Development of the Ureteric Bud and Renal Collecting System. Keio J Med 57:184-189

25. Yu Z-Y, Chen L-S, Zhang L-C, Zhou T-B (2012) Meta-analysis of the relationship between ACE I/D gene polymorphism and end-stage renal disease in patients with diabetic nephropathy: ACE and ESRD in DN patients. Nephrology 17:480-487

26. Zhang S-L (2004) Angiotensin II Increases Pax-2 Expression in Fetal Kidney Cells Via the AT2 Receptor. J Am Soc Nephrol 15:1452-1465

27. Zhou T-B, Lin N, Liu Y-G, Qin Y-H, Shao M-B, Peng D-D (2012) Association of ACE I/D gene polymorphism with vesicoureteral reflux susceptibility in children: a meta-analysis. J Renin Angiotensin Aldosterone Syst 13:273-281 


\section{Tables}

Table 1 - Genotype and allele frequency of $A C E$ gene insertion/deletion (I/D) in individuals with CAKUT (Cases) and health controls (Controls).

\begin{tabular}{|c|c|c|c|c|c|c|c|c|}
\hline \multirow[b]{2}{*}{ Variant } & \multicolumn{2}{|c|}{$\begin{array}{l}\text { Cases } \\
(n=225)\end{array}$} & \multicolumn{6}{|c|}{$\begin{array}{l}\text { Controls } \\
(n=210)\end{array}$} \\
\hline & $\mathrm{N}$ & $\%$ & $\mathrm{~N}$ & $\%$ & $\begin{array}{l}\mathrm{P}- \\
\text { value }\end{array}$ & $\begin{array}{l}\text { Permutation } \\
\text { P-value }\end{array}$ & $\begin{array}{l}\text { Odds- } \\
\text { ratio }\end{array}$ & $95 \% \mathrm{Cl}$ \\
\hline \multicolumn{9}{|c|}{$\begin{array}{l}A C E \text { insertion/deletion (I/D) } \\
\text { polymorphism }\end{array}$} \\
\hline DD & 74 & 32.9 & 67 & 31.9 & 0.906 & 0.906 & 1.0 & \\
\hline ID & 110 & 48.9 & 107 & 51 & & & 0.93 & $\begin{array}{l}0.61 \\
- \\
1.42\end{array}$ \\
\hline II & 41 & 18.2 & 41 & 17.1 & & & 1.03 & $\begin{array}{l}0.59 \\
- \\
1.80\end{array}$ \\
\hline D & 258 & 57.3 & 241 & 57.4 & 0.989 & 0.953 & 1.0 & \\
\hline I & 192 & 42.7 & 179 & 42.6 & & & 1.002 & $\begin{array}{l}0.77 \\
- \\
1.31\end{array}$ \\
\hline
\end{tabular}

Table 2 - Genotype and allele frequency of $A C E$ gene insertion/deletion (I/D) in individuals with ureteropelvic junction obstruction (Cases) and health controls (Controls). 


\begin{tabular}{|c|c|c|c|c|c|c|c|c|}
\hline \multirow[b]{2}{*}{ Variant } & \multicolumn{2}{|c|}{$\begin{array}{l}\text { Cases } \\
(n=59)\end{array}$} & \multicolumn{6}{|c|}{$\begin{array}{l}\text { Controls } \\
(n=210)\end{array}$} \\
\hline & $N$ & $\%$ & $\mathrm{~N}$ & $\%$ & $\begin{array}{l}\mathrm{P}- \\
\text { value }\end{array}$ & $\begin{array}{l}\text { Permutation } \\
\text { P-value }\end{array}$ & $\begin{array}{l}\text { Odds- } \\
\text { ratio }\end{array}$ & $95 \% \mathrm{Cl}$ \\
\hline \multicolumn{9}{|c|}{$\begin{array}{l}A C E \text { insertion/deletion (I/D) } \\
\text { polymorphism }\end{array}$} \\
\hline $\mathrm{DD}$ & 23 & 38.9 & 67 & 31.9 & 0.487 & 0.468 & 1.0 & \\
\hline ID & 25 & 42.4 & 107 & 51 & & & 0.68 & $\begin{array}{l}0.35 \\
- \\
1.29\end{array}$ \\
\hline II & 11 & 18.6 & 36 & 17.1 & & & 0.89 & $\begin{array}{l}0.39 \\
- \\
2.03\end{array}$ \\
\hline D & 71 & 60.2 & 241 & 57.4 & 0.586 & 0.594 & 1.0 & \\
\hline I & 47 & 39.8 & 179 & 42.6 & & & 0.89 & $\begin{array}{l}0.58 \\
- \\
1.35\end{array}$ \\
\hline
\end{tabular}

Table 3 - Genotype and allele frequency of $A C E$ gene insertion/deletion (I/D) in individuals with vesicoureteral reflux (Cases) and health controls (Controls).

\begin{tabular}{|c|c|c|c|c|c|c|c|c|}
\hline \multirow[b]{2}{*}{ Variant } & \multicolumn{2}{|c|}{$\begin{array}{l}\text { Cases } \\
(n=51)\end{array}$} & \multicolumn{2}{|c|}{$\begin{array}{l}\text { Controls } \\
(n=210)\end{array}$} & \multirow[b]{2}{*}{$\begin{array}{l}\mathrm{P}- \\
\text { value }\end{array}$} & \multirow[b]{2}{*}{$\begin{array}{l}\text { Permutation } \\
\text { P-value }\end{array}$} & \multirow[b]{2}{*}{$\begin{array}{l}\text { Odds- } \\
\text { ratio }\end{array}$} & \multirow[b]{2}{*}{$95 \% \mathrm{Cl}$} \\
\hline & $\mathrm{N}$ & $\%$ & $\mathrm{~N}$ & $\%$ & & & & \\
\hline \multicolumn{9}{|c|}{$\begin{array}{l}A C E \text { insertion/deletion (I/D) } \\
\text { polymorphism }\end{array}$} \\
\hline DD & 23 & 29.1 & 67 & 31.9 & 0.876 & 0.880 & 1.0 & \\
\hline ID & 41 & 51.9 & 107 & 51 & & & 1.12 & $\begin{array}{l}0.62 \\
- \\
2.02\end{array}$ \\
\hline II & 15 & 19 & 36 & 17.1 & & & 1.21 & $\begin{array}{l}0.56 \\
- \\
2.61\end{array}$ \\
\hline D & 87 & 55.1 & 241 & 57.4 & 0.616 & 0.592 & & \\
\hline I & 71 & 44.9 & 179 & 42.6 & & & & \\
\hline
\end{tabular}

Table 4 - Genotype and allele frequency of $A C E$ gene insertion/deletion (I/D) in individuals with multicystic dysplastic kidney (Cases) and health controls (Controls). 


\begin{tabular}{|c|c|c|c|c|c|c|c|c|}
\hline \multirow[b]{2}{*}{ Variant } & \multicolumn{2}{|c|}{$\begin{array}{l}\text { Cases } \\
(\mathrm{n}=51)\end{array}$} & \multicolumn{6}{|c|}{$\begin{array}{l}\text { Controls } \\
(n=210)\end{array}$} \\
\hline & $N$ & $\%$ & $\mathrm{~N}$ & $\%$ & $\begin{array}{l}\mathrm{P}- \\
\text { value }\end{array}$ & $\begin{array}{l}\text { Permutation } \\
\text { P-value }\end{array}$ & $\begin{array}{l}\text { Odds- } \\
\text { ratio }\end{array}$ & $95 \% \mathrm{Cl}$ \\
\hline \multicolumn{9}{|c|}{$\begin{array}{l}A C E \text { insertion/deletion (I/D) } \\
\text { polymorphism }\end{array}$} \\
\hline DD & 19 & 36.5 & 67 & 31.9 & 0.685 & 0.624 & 1.0 & \\
\hline ID & 23 & 44.2 & 107 & 51 & & & 0.76 & $\begin{array}{l}0.38 \\
- \\
1.50\end{array}$ \\
\hline II & 10 & 19.2 & 36 & 17.1 & & & 0.98 & $\begin{array}{l}0.41 \\
- \\
2.33\end{array}$ \\
\hline D & 61 & 58.7 & 241 & 57.4 & 0.814 & 0.786 & 1.0 & \\
\hline I & 43 & 41.3 & 179 & 42.6 & & & 0.95 & $\begin{array}{l}0.61 \\
- \\
1.47\end{array}$ \\
\hline
\end{tabular}

